\title{
BRYORIA FORSTERI (LICHENIZED ASCOMYCOTINA), A NEW SPECIES FROM ANTARCTICA
}

\author{
MARIA OLECH ${ }^{1,2}$, JAN BYSTREK $^{3,4}$ \\ ${ }^{1}$ Institute of Botany, Jagiellonian University \\ Kopernika 27, 31-501 Kraków, Poland \\ e-mail: olech@ib.uj.edu.pl \\ ${ }^{2}$ Department of Antarctic Biology, Polish Academy of Sciences \\ Ustrzycka 10, 02-141 Warszawa, Poland \\ ${ }^{3}$ Institute of Biology, University of Białystok \\ Świerkowa 20B, 15-328 Białystok, Poland \\ ${ }^{4}$ Institute of Biology, Maria Skłodowska-Curie University \\ Akademicka 15, 20-033 Lublin, Poland
}

(Received: September 15, 2003. Accepted: January 15, 2004)

\begin{abstract}
Bryoria forsteri Olech \& Bystr. is described as new to science. The species is endemic to Antarctica and differs from its nearest relative Bryoria chalybeiformis (L.) Brodo \& D. Hawksw. in the lack of soralia; lack of proper pseudocyphellae; absence of fumarprotocetraric acid; in the different structure of the cortex and by having another kind of photobiont.
\end{abstract}

KEY WORDS: lichenized Ascomycotina, taxonomy, Bryoria forsteri sp. nov., Antarctica, South Shetland Islands.

\section{INTRODUCTION}

In the course of studies on the flora of lichenized Ascomycotina on King George Island (South Shetland Islands, Antarctica), Bryoria genus was made the subject of critical revision. The present paper is based upon the conclusion of the taxonomic revision of the genus Bryoria. The examination of the collected material has revealed a new species of the genus, which is described in this paper.

\section{MATERIAL AND METHODS}

The research was carried out during the Polish Antarctic Expedition to the Henryk Arctowski Station, organized by the Polish Academy of Sciences. The material was collected in austral summer of 2001/2002 on the western shores of Admiralty Bay (King George Island), and additional samples were collected during the 1986-1988, and 1990-1991 seasons in the ice-free areas of King George Island and Livingston Island (South Shetlands). We have also had the opportunity to study the herbarium collections of Lublin University. The studies employed chemical spot tests of thallus tissue and thin-layer chromatography (TLC).

\section{RESULTS}

Bryoria forsteri Olech \& Bystr. sp. nov. (Fig. 1)

Thallus filamentoso-fruticulosus, $5-15 \mathrm{~cm}$ longus, rarius paullo longior, prostratus, juvenilis ascendens, substratu parte basali et basalibus secundariis ad apices nonnullem ramosum formatis affixus, nitidus, glaber, fusco-niger vel niger, ad summitates niger, medelfactus olivascente-niger, passim parte inferiore et parte mediale pallidioribus. Rami supra basin usque ad $0.5 \mathrm{~cm}$ in diametro, paullo crassiores, paullo serpentino fleuxuosi, in tota longitudine pluries repetitio dichotome vel subdichotome irregulariter ramosi, ramuli varie longi. Rami in parte inferiore et parte mediali distincte deformati, irregulariter complanati, perforati foveolati et rugosi. Ramuli tenuiores teretes, hic illinc prope ramificationes vulgo paullo complanate, ad apices capillari, ad ramos juniores furcati. Ramuli leterales spinuliformes, minus numerose, fere perpendiculares arcuato deflexi. Anguli inter ramos recti, passim pervii, inter teniuores angusti. Pseudocyphella ignota, rare fissuris longitudinalibus pseudocyphellis similibus, ex hyphis leptodermaticus inaqualiter. 


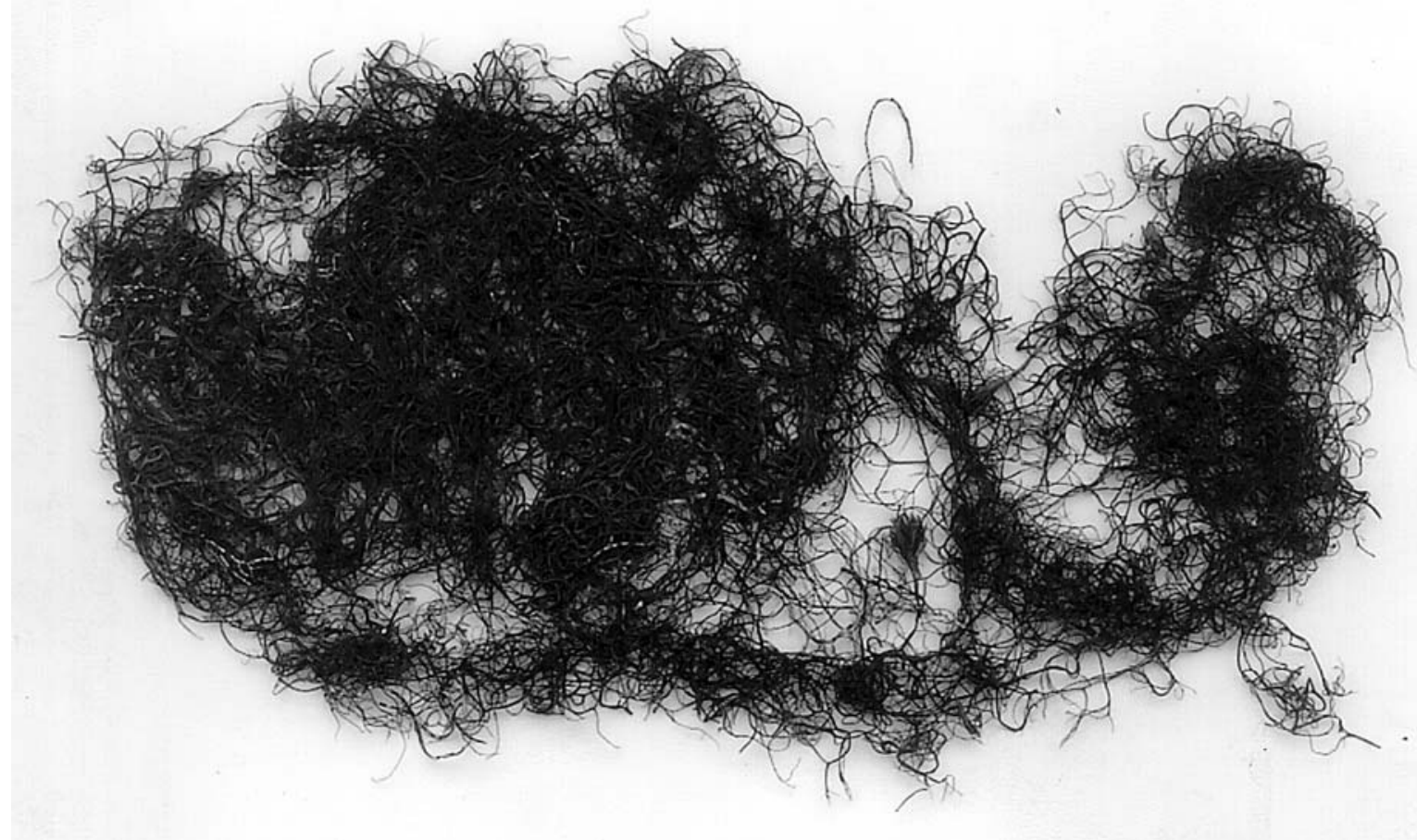

Fig. 1. Bryoria forsteri Olech \& Bystr.

Structura anatomica: Cortex ca 10-50 $\mu \mathrm{m}$ crassus, ex hyphis formatus longitudianalibus, conglutinalis, extus obscure infuscatus, pachydermaticus usque ad $2 \mu \mathrm{m}$ lati, luminibus cellularum usque ad 5 um lati, et ex hyphis incoloribus (pseudocyphells similibus), intus ex hyphis incoloribus, ramificantibus ininaequaliter, leptodermaticus, in tota periphaeria inaequaliter sinuoso inaequalis, Medulla laxissima paraplectenchymatica Fotobiont Lobosphaera sp. in medulla plerumque tantum sub cortice formata. Autosporangia numerosa.

Apothecia, soralia et pycnidia ignota.

Reactiones chemicae: cortex et medulla Pd-, C-, K-, KC-.

Locus classicus: Antarctica, South Shetland Islands, King George Island, Admiralty Bay region, Point Thomas: Moraines by the northern edge of Ecology Glacier, 50 $\mathrm{m}$ a.s.1. (lat. $62^{\circ} 10^{\prime} \mathrm{S}$, long $58^{\circ} 25^{\prime} \mathrm{W}$ ), on Polytrichastrum alpinum moss, 7.01.2002, 1g. M. Olech [A 180-11 KRA-Holotypus, O-1Bfo 01 LBL-L - Syntypus].

Thallus, fruticose, $5-15 \mathrm{~cm}$, rarely slightly longer, spread on substrate (gametophytes of mosses), rising up when young, attached to the substrate by its base and tips of branches, smooth and glossy, brown-black, sometimes paler in the central and lower parts. Branches of $0.5 \mathrm{~cm}$ diameters above their bases, thicker in places, in other places bent into a serpent-like shape, dichotomously branching in many places along their entire lengths, branches of uneven lengths. Branches malformed in their lower and middle parts, flattened irregularly, hairy at the tips, the youngest branches dichotomous. Lateral branches are few, hook-shaped, arched, with lateral spinules present. Angles between the branches are wide, sometimes obtuse, but between younger branches - narrow. Pseudocyphellae - not known, rarely pseudocyphellae-like cracks formed by thin hyphae (visible under microscope).
Anatomical structure: Cortex ca 10-50 $\mu \mathrm{m}$ thick, fibrous, the outer part formed by thick brown hyphae of diameter up to $8 \mu \mathrm{m}$, with cell diameters up to $5 \mu \mathrm{m}$, and by thin-walled colourless hyphae; the inner part formed by colourless thinwalled hyphae, rarely branched, thin-walled of up to $2 \mu \mathrm{m}$ in diameter, with uneven inside. Medulla very loose, paraplenctenchymatous. Photobiont cf. Lobosphaera sp. (not Trebouxia), cells of variable size (from $10020 \mu \mathrm{m}$ ) in the medulla chiefly beneath the cortex. Numerous autosporangia.

Apothecia, soralia and pycnidia not present.

Chemical properties: K-, C-, KC-, Pd-. It does not contain fumarprotocetraric acid or other lichen compounds.

Ecology and distribution: The thallus of Bryoria forsteri grows on mosses, chiefly Polytrichastrum alpinum, on glacial moraines, in flat places sheltered from winds, and also on nunataks and flat rock plateaus. It is associated with such species as: Usnea antarctica, Ochrolechia frigida, Cetraria aculeata, Deschampsia antarctica, Hypogymnia lugubris, Rinodina olivaceobrunnea, Sphaerophorus globosus, and Parmelia saxatilis.

Note: Bryoria forsteri is a distinct species. In earlier studies (Lamb 1964, 1970; Lindsay 1969; Smith 1972, 1996; Allison \& Smith 1973; Andreev 1988; Jacobsen \& Kappen 1988; Olech 1989, 1993; Sancho et al. 1990, 1999; Piovano et al. 1991; Inoue 1993a; Tatur et al. 1997) there were reports on the occurrence in Antarctica of Bryoria chalybeiformis (L.) Brodo \& D. Hawksw. but, according to Øvstedal \& Smith (2002), they were erroneous.

Bryoria forsteri differs from $B$. chalybeiformis in external morphology, a thin cortex and its specific sculpture, in a lack of proper pseudocyphellae, and having another kind of photobiont, lacking colour chemical reactions with $\mathrm{K}, \mathrm{C}$, $\mathrm{KC}, \mathrm{Pd}$, and lacking fumarprotocetraric acid. 
Additional specimens examined: King George Island, Admiralty Bay region. Bransfield Strait: The Tower SE 300m a.s.1. 3.12.1987, Baszta NE 150 m a.s.1. 12.12.1987, Olech A180-17 (KRA); Olech A 180-12 (KRA); Bastion N 230 m a.s.1., 12.12.1987, Olech A 180-13 (KRA); Demay SE 100 m a.s.1., 10.12.1987, Olech A 180-14 (KRA); Demay NE $160 \mathrm{~m}$ a.s.1., 2.02.1987, Olech A 180-15 (KRA); Creeping Slopes NE 110 m a.s.1., 2.02.1987, Olech A 180-16 (KRA);. Ecology Glacier: Sphinx Hill N 110 $\mathrm{m}$ a.s.1. 22.01.1988, Olech A 180-18 (KRA); Rescuers Hills N 90 m a.s.1., 22.01.1988, Olech A 180-19, NE 70 m a.s.1., 22.01.1988, Olech A 180-20 (KRA); Point Thomas: Jersak Hills E 150 m a.s.1., 11.03.1987, Olech A 18021 (KRA); SE $190 \mathrm{~m}$ a.s.1., 2.05.1987, Olech A 180-22 (KRA). Martel Inlet: Smok N 130 m a.s.1., 1.11.1987, Olech A 180-23; Mount Wawel 90 m a.s.1., 21.01.1990, Olech A 180-24. Vieville Glacier; Vaureal Peak SW 35 m a.s.1., 19.01.1987, Olech A 180-25; Vaureal Peak W 90 m a.s.1., 18.01.1988, Olech A 180-26 (KRA). Livingston Island, South Bay region. Johnsons Dock: Ballester Point NW 20 m, Olech A. (KRA).

Bryoria forsteri is named after George (Jerzy) Adam Forster, a scientist hailing from Gdańsk, born as a subject of the King of Poland, who took part in James Cook's expedition (1773-1775) - the first ever to cross the southern polar circle and circumnavigate Antarctica.

\section{ACKNOWLEDGEMENTS}

The authors are grateful to Dr. M. Wayda, for checking the Latin description and to Dr. P. Osyczka, for his helpful assistance in study of species chemistry. Part of this work was supported by a Grant PB 6PO4GO2219 from the State Committee for Scientific Research (KBN).

\section{LITERATURE CITED}

ALLISON J.S., SMITH R.I. LEWIS. 1973. The vegetation of Elephant Island, South Shetland Islands. Bull. Brit. Antarc. Surv. 33-34: 185-212.

ANDREEV M.P. 1988. De lichenoflora insulae King-George (Antarctis) notula. Nov. Syst. Plant Vasc. 25: 118-124.
INOUE M. 1993. Floristic notes on lichens in the Fildes Peninsula of King George Island and Harmony Cove of Nelson Island, South Shetland Islands the Antarctic, Proc. NIPR Symp. Polar Biol. 6: 106-120.

JACOBSEN P., KAPPEN L. 1988. Lichens from the Admiralty Bay region, King George Island (South Shetland Islands, Antarctica). Nova Hedwigia 46 (3-4): 503-510.

LAMB I.M. 1964. Antarctic lichens I. The genera Usnea, Ramalina, Himantormia, Alectoria, Cornicularia. Br. Antarct. Surv. Sci. Rep. 38: 1-34.

LAMB I.M. 1970. Antarctic terrestrial plants and their ecology. in: Antarctic Ecology. 2: 733-751. ed. by M.W. Holdgate. Academic Press. London.

LINDSAY D.C. 1974b. The macrolichens of South Georgia. Br. Antarct. Surv. Sci. Rept. 89: 1-91.

OLECH M. 1989a. Lichens from the Admiralty Bay region, King George Island (South Shetland Islands, Antarctica). Acta Soc. Bot. Pol. 58 (3): 493-512.

OLECH M. 1993. Lower Plants. In: Rakusa-Suszczewski S. (ed.) Zatoka Admiralicji. Ekosystem Strefy Przybrzeżnej Morskiej Antarktyki. Oficyna Wydawnicza, Instytut Ekologii PAN, Dziekanów Leśny. p. 241-246. (in Polish)

ØVSTEDAL D.O., LEWIS SMITH R.I. 2001. Lichens of Antarctica and South Georgia. A Guide to their identification and ecology. Cambridge University Press: 411.

PIOVANO M., GARBARINO J.A., CHAMY M.C., ZUNIGA V., MIRANDA C., CESPEDES E., FIEDLER P., QUILHOT W., ARAYA G. 1991. Studies on Chilean lichens, XVI. Advances in the chemistry of secondary metabolites from Antarctic lichens. Inst. Antart. Chileno, Ser. Ci. 41: 79-90.

SANCHO L.G., KAPPEN L., SCHROETER B. 1990. Primeros datos sobre la Flora y Vegetaction Liquenica de Isla Livingston (Islas Shetland del sur, Antartida). In: Actas del Tercer Symposium Espańol de Estudios Antarcticos. Comision Interministerial de Ciencia y Technologia, Madrid 94-99.

SANCHO L.G., SCHULZ F., SCHROETER B., KAPPEN L. 1999. Bryophyte and lichen flora of South Bay (Livingston Islad: South Shetland Islands, Antarctica). Nova Hedwigia 68 (3-4): 301-337.

SMITH R.I. LEWIS 1972. Vegetation of the South Orkney Islands with particular reference to Signy Island. Br. Antarct. Surv. Scient. Reps. 68: 1-124.

SMITH R.I. LEWIS. 1996. Terrestrial and freshwater biotic components the western Antarctic Peninsula. Foundations for ecological research west of the Antarctic Peninsula. Antarctic Research Series. 70: 15-59.

TATUR A., MYRCHA A., NIEGODZISZ J. 1997. Formation of abandoned penguin rookery ecosystems in the Maritime Antarctic. Polar Biology 17: 405-417. 